\title{
Enganging Secularization with Expository Preaching
}

\author{
Frederich Oscar L. Lontoh
}

\author{
Evangelical Theological Seminary of Indonesia - Surabaya \\ E-mail: oscarlontoh@sttii-surabaya.ac.id
}

\begin{abstract}
This research trying to see the phenomenon of secularization that is dominating the world. Some people argue that secularization is dangerous for the Christian faith while some say that it is just the opposite that secularization is necessary. What is developing now is that secularization becomes a movement in personal thought. Some experts distinguish between secularization and secularism. Secularism is a kind of ideology that remove everything supernatural defining ones life. Secularism refers to the fact that religion has lost influence on the societal, the institutional and the individual levels.

Preaching is a main part of church to educate the congregation about God, what His will and also supernatural being. Expository preaching is the method of teaching scripture. There are many other ways to preach a sermon that are beneficial to a congregation. However, that these other forms of preaching should never replace expository preaching in the life of the church. Solid expository preaching brings scripture to life. It connects the meaning of the passage to the life of the hearer, helping them to apply what they've heard to their specific life situations. This is the way to maintain people from leaving God and supernatural being in modern human life.
\end{abstract}

Keywords: Secularization, Secularism, Expository Preaching

\section{INTRODUCTION}

A 2015 poll jointly conducted by NBC and The Wall Street Journal found that 21 percent of Americans feel that religion is losing importance in their lives, and a Gallup poll from the same year found that one in five American adults has no formal religious identification.

An earlier study conducted by Pew Research Center similarly found an alarming dip in American religiosity and a sharp rise among the religiously unaffiliated, or "nones."

A previous survey conducted also by the Pew Research Center's Forum on Religion and Public Life in June 2012 [1] it was found that out of nearly 2,200 evangelical leaders from 166 countries, $71 \%$ identified secularism as a major threat to Evangelical Christianity, also adding Consumerism (67\%) and sex and violence in pop culture $(59 \%)$.

Regarding biblical interpretation, morality and drinking alcohol, more than half of the respondents (52\%) said that drinking alcohol had nothing to do with being a good evangelical, while the rest (42\%) said it has relevance.
Forty-nine percent (49\%) of those surveyed agree that to be moral people do not need to believe in God.

\begin{tabular}{|c|c|}
\hline \multicolumn{2}{|c|}{ The leaders surveyed ocerwehelning by agree that. } \\
\hline $\begin{array}{l}\text { Christianity is the one, true faith } \\
\text { leading to eternal ife }\end{array}$ & 96 \\
\hline The Bible is the Word of God & 93 \\
\hline Abortion is ususlly or always wrong & 96 \\
\hline Society should discourage homosexuality & 34 \\
\hline $\begin{array}{l}\text { Men have a duty to serve as the reliclous } \\
\text { leaders in the marriace and family }\end{array}$ & 79 \\
\hline \multicolumn{2}{|l|}{ But they disagree on whether... } \\
\hline $\begin{array}{l}\text { The Bible should be read literally. } \\
\text { word for word. }\end{array}$ & 50 \\
\hline $\begin{array}{l}\text { or not evervihing in the Bible } \\
\text { should be taken literally }\end{array}$ & 48 \\
\hline $\begin{array}{l}\text { it is necessary to believe in God } \\
\text { to be a moral person }\end{array}$ & 49 \\
\hline $\begin{array}{l}\text { oe it is not necessary to believe in God } \\
\text { to be a moral person }\end{array}$ & 49 \\
\hline $\begin{array}{l}\text { Drinking alcohol is compatible } \\
\text { with being a good evaneelical }\end{array}$ & 42 \\
\hline $\begin{array}{l}\text { oe drinking alcohol is not compatible } \\
\text { with beling a cood evangelical }\end{array}$ & 52 \\
\hline
\end{tabular}




\section{Major Threats to Evangelical Christianity}

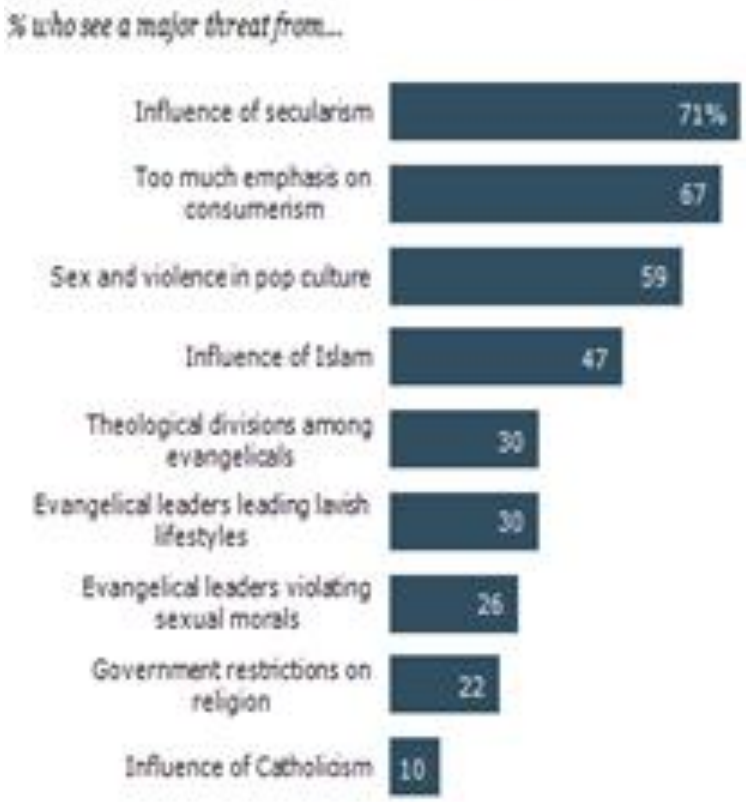

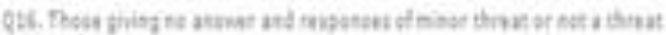
in sutikines.

NEN RESEAGC CENTERS PORUM ON REUGION B PUBUC IFE

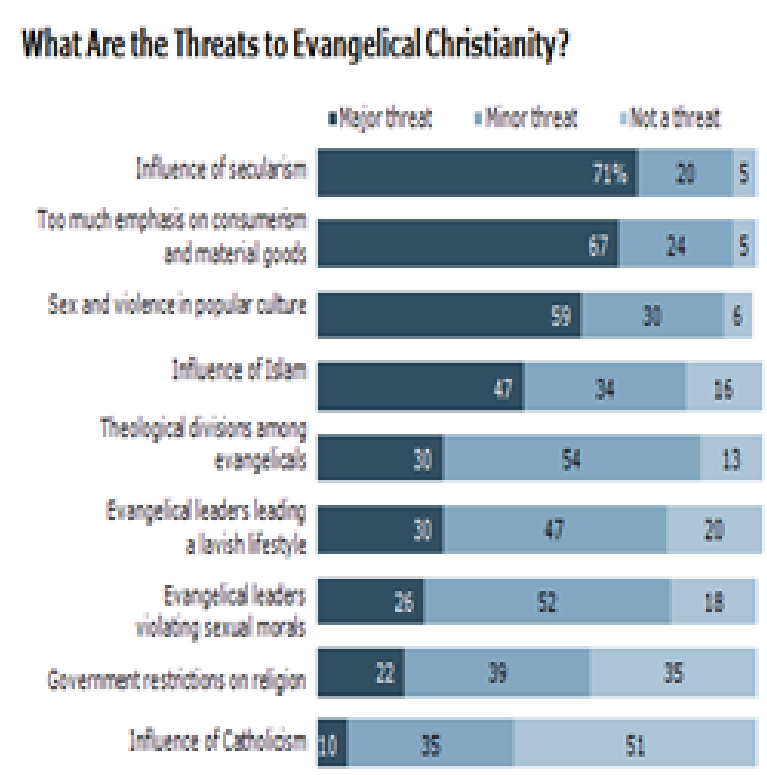

\section{Widespread Agreement on Strategies for Evangelization}

$\begin{array}{lr}\text { Evangelization efforts should focus more on.. } & \% \\ \text { Changing individual hearts } & 80 \\ \text { Reforming social institutions } & 16 \\ \text { No answer } & 4\end{array}$

Itismare effective to... Empower local missionaries $\quad 85$ Send missionaries to other countries $\quad 12$ No answer

\section{PEE RESELACH CEITER'S FORUM ON RELIGION B PUBUC UFE}

From the data above, we can see that secularization could be a latent danger that is not visible but its existence can be felt by everyone. How the Church respond to secularization?

\section{SECULARIZATION}

The Term "secularization" has a long history. Etymologically the word secularization comes from the Latin term saeculum, which was used by Augustine and the early church fathers to mean the "temporary world". It was later employed in the Middle Ages by canon law to indicate a monk abandoning the regimen of his order, who was secularized by returning to the world.[2] The Renaisance in the West towards the end of the 16th century, naturally influenced the way humans perceive them selves and encouraged them to review their relationship with the (Ultimate Reality) commonly called God.[3] The orientation changes that occurred at this time had a very broad and profound impact. A sociologist Karel Dobbelaere in his article " The Meaning and Scope of Secularization " in the Oxford Handbook of Sociology of Religion argues that "Secularization theory is a process by which overarching and transcendent religious systems of old are confined in modern functionally differentiated societies to a subsystem alongside other subsystems, 
losing in this process their overarching claims over these other subsystems"'[4] As an idea in the field of sociology, according to Tschannen secularization is "the process of developing modern societies whereby religious doctrines and organizations experience diminished social influence because of the expansion of rationalism, science and technology that accompanies the process of industrialization and urbanization. This is a complex process that entails many individual, social and political dimensions within religion."[5] In the view of Peter L. Berger secularization is understood as "the process of all sectors of life in society and culture released from the domination of institutions and religious symbols."[6] He noted various factors as drivers of secularization, including human civilization as a whole that spread throughout the world; the dynamics generated by industrial capitalism; lifestyle caused by industrial production; the influence of modern science that permeates various sectors of social life; practical infrastructure in social life.[7]

Berger further explained that of the many factors, the factors that are the roots and seeds of secularization are Western religious traditions, especially the religious traditions of Judaism which through Christianity, especially the Reformist Calvinist Christian tradition, have become the foundations of modern civilization. Berger emphasized that the modern world, with its secularisation, could be interpreted as "a realization of Christian spirit" and "Protestantism has played a distinctive role in upholding the modern world."[8] Unlike the Roman Catholic Church where religious ritual practices are full of traditional nuances and the charm of magical liturgy, the life of the Protestant Church experienced a lot of "disenchantment of the world" (Entzauberung der Welt), and has "lost its nuance of salvation". There are no statues of angels, no statues of saints and statues of the Virgin Mary as intermediaries of salvation, no bread and wine that turn into the flesh and blood of Christ.[9] According to Cornelis Van Peursen, as quoted by Harvey Cox, defining secularization as "Human liberation" first from religion and from the metaphysical problem which governs reason and language, which means: "The world apart from false religious notions, the obscurity of all closed world views, the breaking of all supernatural myths and sacred symbols so that he could no longer blame fate or misfortune for what he did with him; it is humans who divert their attention away from the worlds up there toward this world and the present."[10]
This means that secularization is something that refers to the direction of change and the replacement of things that are supernatural and theological into things that are natural in the framework of the world of science that is all scientific and argumentative.[11] The term Secularization is also used by sociologists in sociology. In sociology, secularization has several definitions and all relate to religious deaths.

The interesting point for evangelicals is, if in the beginning secularization emphasized the separation between Christian institutions or organizations with social rules but what is developing now is that secularization becomes a movement in personal thought. According to Vernon Pratt

"I believe that the scientific conceptual framework with which we are living today has no place for the concept of the supernatural, and it is this circumstance with the 'secularisers' of Christianity - that is, those Christians who are attempting to preserve their religion in the face of secularization - are feeling it to face. They are attempting to 'desupernaturalise' a 'supernatural' religion, because the notion of the supernatural no longer has any meaning."[12] He claims that most Christians believe and can explain God, angels, miracles and many supernatural things and they believe and understand it well, but they cannot explain their coherent account with this natural world.

Basically, he claims that although people often think they know what these ideas mean, no coherent accounts can eventually be given to them.

This then led to the notion that the supernatural concept were not in line with the concept of science. Because science views that everything happens based on something that is logical and scientific, scientists see that the supernatural thing is something that is not the same as natural law. Pratt states that this difference can occur because each view priorities of its own methodology.

A Canadian philosopher Charles Taylor, in struggling with the term "secular", or "secularity" was trying to make distinguish into three senses which is all three modes of secularity make reference to "religion": as that which is retreating in public space (1), or as a type of belief and practice which is or is not in regression (2), and as a certain kind of belief or commitment whose conditions in this age are being examined (3).[13] Taylor, in contrast, sees science as reinforcing religion, since God is implicated in a social existence where the contemplation of meaning and order suggests "something divine in us." 
For Taylor, belief is not what science finds but what religion hopes for.

Taylor believes that Western liberal thought, beginning with Hobbes and Locke, Hume and Adam Smith, is on the wrong track.

"A Secular Age" is a work of stupendous breadth and erudition, even if repetitious. While Taylor's main purpose is to salvage religion from the corrosive effects of modern secularism.

Long before Taylor's 'The Secular Age' book appeared, in 1965, Harvey Cox, a Babtist theologian from America and the theology professor from Harvard University was known as one of the radical theologians or secular theologians. Like most radical theologians, Cox is also known to argue that our traditional language about God is outdated, but he believes we can still talk about God in the midst of existing secularization. Cox emphasized that his theology was theology of social change.

The criteria of truth according to Cox's theology are inclined to the pragmatic truth of the truth of metaphysics. The validity of Christianity is whether it moves us to fulfill human needs today. Sin is defined as a rebellion against social change. As well as slowness and laziness.

Secularization was a logical consequence of biblical faith. Harvey Cox says

"There are three elements in biblical faith that have each given rise to one aspect of secularization. Thus, the disenchantment of nature begins with Creation, the sacralization of politics with Exodus and deconsecration of values with the Sinai Covenant especially with prohibition of idols."[14] This is to distinguish it from Karl Barth's Word of God theology and the founding theology of religious experience of Schleiermacher.

Cox's theology is oriented towards secularization in modern life. He accepted secularization; for him it was important to free man from religious and metaphysical lessons. But Cox also realized that secularization could also be dangerous if followed by secularism, where secularism is absolutizing of the value of this world.

Cox is more tolerant of worldly matters. According to Bloesch.

"Recently he has become more tolerant of such magazines as Playboy, and also more relativistic in his sexual ethics."[15] Cox seems more open and accepts secularization. He is also not afraid of urbanization. instead he saw a new opportunity to spread Christianity in this urban and secular world. In order to reach secular people for the gospel he stated:

"If neither "premetaphysical" nor existentialist language will reach urbansecular man, why do we believe a political theology will? The reason is that in secular society politics does what methaphysics once did. It brings unity and meaning to human life and thought. [16]

\section{SECULARISM}

According to the Merriam Webster Dictionary Secularism is indifference to or rejection or exclusion of religion and religious considerations.[17] Secularism also means the quality of behaving in a way that shows religion does not influence you. [18] Secularism is an attitude or political ideology aiming to eradicate religion from public and social life, or at least regulate and control religion, and especially limit its influence on state politics.[19] An English writer named George Jacob Holyoake in 1851 was the first use the word "secularism" [20] Holyoake used the word to popularize the separation of social and religious rules without criticizing belief in religion.

He asserted that secularism is not an argument that opposes Christianity but something that stands alone. Secularization is also not a demand on Christianity, according to his view.Secularism also does not say that there is no light or guidance in but Holyoake argues that there is light and guidance in secular truths but with conditions and sanctions that exist independently. He also added that "Secular knowledge is manifest that kind of knowledge which is founded in this life, which relates to the conduct of this life, conduces to the welfare of this life, and is capable of being tested by the experience of this life.' [21] In his publication in 1896 English Secularism, Holyoake explains secularism as follows:

"Secularism is a code of duty pertaining to this life, founded on considerations purely human, and intended primarily for those who find theology indefinite or inadequate, unreliable or unbelievable. Its essential principles are three: (1) The improvement of this life by material means. (2) That science is the available Providence of man. (3) That it is good to do good. Whether there be other good or not, the good of the present life is good, 
and it is good to seek that good."[22] In relation to Christianity he says,

"Secularism is not an argument against Christianity, it is one independent of it. It does not question the pretensions of Christianity; it advances others. Secularism does not say there is no light or guidance elsewhere, but maintains that there is light and guidance in secular truth, whose conditions and sanctions exist independently, and act forever. Secular knowledge is manifestly that kind of knowledge which is founded in this life, which relates to the conduct of this life, conduces to the welfare of this life, and is capable of being tested by the experience of this life.' '[23] Cox distinguishes Secularization and Secularism. According to Cox Secularism on the other hand is a name for ideology, a new world view that is very close to its function as a new religion. Cox stressed that

"While Secularization find its roots in biblical faith itself and to some extent an authentic outcome of the impact of bibilical faith on Western history, this is not the case of secularism. It's a closed ism. It menaces the openness and freedom secularization has produced; it must therefore be watched carefully to prevent its becoming the ideology of a new establishment. It must be especially checked where it pretends not to be a world view but none the less seek to impose its ideology through the organs of state."[24] According to Cox, there are several forms of secularization that he explained in his book "Secular City". Pragmatism and profanity. Pragmatism [25], "means that secular man's concern is with the question "will it work?" Secular man does not occupy himself much with mysteries. $\mathrm{He}$ is little interested in anything that seems resistant to application of human energy and intelligence. He judges ideas, as the dictionary suggests in its definition of pragmatism, by the 'result they will achieve in practice'. The world is viewed not as a unified methaphysical system but a series of problems and projects." While by profanity [26]: "We refer to secular man's wholly terrestrial horizon, the disappearance of any supramundane reality defining his life. Pro-fane means literally 'outside the temple' thus ' having to do with this world'. By calling him profane we do not suggest that secular man is sacrilegious, but that he is unreligious. He views the world not in terms of some other world but in term of itself

Beside pragmatism, and profanity, there are two more characteristics that Cox puts forward namely pluralism and tolerance. In the secular society he points to, the difference in "world views", including differences in "religion",which peacefully coexist without the devastating fanaticism that we see in history. Cox agrees that religion, whatever that is relevant to religion, can withstand secularization. But in this case, he argued, it would be like a hobby, 'national identification', or 'esthetic delight'. It is no longer a system of government in terms of personal values and exclusive explanations for a large number of people.

Cox cleverly argues that social society is a society characterized by pluralism, tolerance, pragmatism, and profanity, as well as 'mobility' and 'anonymity'.

Cox's argument can be understood exactly that the concept of Christianity about the ideal way of life is needed to involve secular forms of society in a meaning that can be explained.

Meanwhile, according to Bryan Wilson in Religion in Secular Society , quoted from Vernon Pratt [27], secularization refers to the fact that religion has lost influence on the societal, the institutional and the individual levels. For him, individual secularization is about the loss of authority of the Churches to define what people should believe, practice and accept as moral principles guiding their lives." In his research, Wilson seems to support and add to Cox's suggestions. In discussing the American community, Wilson explained there are three features that identify secular society: the prevalence there of instrumental values, of rational procedures and of technical methods, and he adds that a secular society is one where 'the sense of sacred, the sense, of sanctity of life, and deep religiuosity are absent.' [28]

\section{SERMON IN THE VIEW OF THEOLOGIANS OF FACING SECULARIZATION}

\section{Barth}

Barth criticizes modern sermons by saying "The emphasis in much of today's preaching has to do with the salvation in the future, something the preacher can help give, instead of speaking of the perfect salvation already accomplished. We only await its final relevance.[29] " He added further "We should contact our message to the political and social upheavels of our time, yet we should preach not social gospel but the Gospel of the Cross."[30] 
Barth emphasized that oral witness must be in line with service and love. Speaking (sermons) and actions must be distinguished, but both cannot be separated.

\section{Emil Brunner}

A pastor and professor of theology from the University of Zurich said "More and more I come to the view that the church nowadays speaks not chiefly to Christians, as it did in the Middle Ages and at the time of the Reformation and even a hundred years ago; it must speak primarily to 'heathen'.” [31]

Brunner emphasises that the theology that is most appropriate to survive an develop and make the Gospel alive in the life of secular human right now is 'missionary theology'.

$\mathrm{He}$ also added that " The one fundamental task of the theologian is to so understand the Gospel that it answers the questions of men of every " present age." If he does not do this, if he ignores the questions of the man of today, then he is ignoring the living man himself and failing to capture his attention."[32]

\section{Rudolf Bultman}

is a professor in the field of New Testament at the University of Marburg, Germany. Theology is centered on the kerygma, the message of the cross. He asserted that the criteria of faith must not be taken from the view of the modern world but from an existing understanding of the New Testament. He argues that mythical things need to be set apart from the New Testament. Because according to him it is these myths that make secular people in modern times reject kerygma. According to him

"The church can establish communication with modern man and speak with an authentic voice only after she has resolutely abandoned mythology." [33]

He says we no longer need to preach about the sacrifice of the cross to atone for sin and resurrection of Jesus from the grave, and also about the miracle of Jesus and he said that all of these were products of mythology.

But we should preach about the torture of death on the cross and the new life that will occur to everyone who finds forgiveness of sins from the cross. We must preach sola gratia and sola fide. That is the message we must preach, that is only because of grace and only through faith we are saved.

The essence of the Christian message according to Bultman
"Is not the historical Jesus but the 'Christ event', which consists not only in the historical death of Christ but also in the proclamation of this death and the acceptance of this message." [34]

\section{Bultman also explained that}

"We meet the living Christ not in the Jesus of history but in the preached word of the cross. The decision to which we are called is accepting the fact that we have been accepted."[35]

Bultman stressed that the main problem in Christianity is a hermeneutical problem. According to him, existential philosophy, especially Heidegger's philosophy, can help us to explain human fall and despair. So it can be able to produce kerygma as a theory that makes sense for modern people. He strongly emphasizes this

"For the possibility of living by the grace of God can, by it's very nature, be given only to me; it is not possibility open to all for the taking. If it were, the very meaning of the revelation - the grace given to man who is nothing before God - would be lost."'[36]

Bultman's contribution in this case is his argument for demythologizing the myths in the Bible so that the original message about faith can be stated.

\section{Dietrich Bonhoeffer}

As with his teacher, Karl Barth, he refused apologetics. According to him "We are not to defend ourselves, but rather only to serve with compassion. We are not to utilize despair for apologetic purposes but only to minister to man in his despair by showing him that God cares. God is to be found not at the boundary of life, but rather in the midst of life. Apologetics is ignoble because it seek to exploit the weakness of man."[37]

So for him to be a concrete witness, we must be witnesses to our lives and work not only through our sermons. Preaching about Christ is basically "to be the love of Christ" itself for our fellowmen. He himself was fascinated by this expression "Jesus sents us as sheep among wolves, not to turn wolves into sheep, but to be eaten by wolves" (Vera Van Trott) He stressed that being a witness of Christ is a witness in suffering.

\section{Billy Graham}

Graham answered a congregation's question about securalization and the end of time "We are living in an increasingly secular and non-religious society, and many people today never think about God or make Him a 
part of their lives," he says.[38] There are several strong reasons why secularism develops. He replied that "we have failed to pass on our faith in Christ to the next generation. Furthermore, not only have we failed to explain the Gospel to them and urge them to commit their lives to Christ, but we have not demonstrated Christ's love by the way we live. We have forgotten Jesus words: 'You are the light of the world ... Let your light shine before others, that they may see your good deeds and glorify your Father in heaven' (Matthew 5:14 , 16)."[39] According to him there are several reasons for our weakening of religion which among others is the development of materialism, a condition in which we are dominated by pleasure, pleasure from secular media, weakening of family ties and the development of immorality.

He remembers that this reminds us of the Bible about the end times that "People will be lovers of themselves, lovers of money, boastful, proud, abusive, disobedient to their parents, ungrateful ... lovers of pleasure rather than lovers of God" ( 2 Timothy 3: 2,4) "But behind the current downturn in the world he also reminds us that God still works today and in many places in other parts of the world many people still come to Christ.

\section{Expository Preaching}

According to a recent Gallup Poll that was done in April of 2017 , 75\% of church goers say that preaching is the most important factor of deciding what church to attend. Also, $76 \%$ of people surveyed said that preaching from the Bible is the most crucial form of preaching. When asked how important is it to have a good music, atmosphere, or visuals, $38 \%$ said that it was important, but not essential. In fact, $61 \%$ believed that not only should those things come second, but they believed that it wasn't something worth discussing. In short, people are hungry for biblical teaching. [41]

There are many models in the delivery of God's word or model in preaching. But if we look and study more deeply with each sermon model then we should get that every true sermon must have the right method of digging as well.

The correct method of excavation is a method used to explore the word of God that is based on rules or methods of hermeneutics. Because in the expository sermon there is a strong and true Bible teaching.
Expository preaching is rarely heard in churches. In general, preachers often use Topical sermons but are not expository.

According to John MacArthur,

"The message finds its sole source in Scripture. The message is extracted from Scripture through careful exegesis. The message preparation correctly interprets Scripture in its normal sense and its context. The message clearly explains the original God-intended meaning of Scripture. The message applies to the Scriptural meaning for today. " [42]

\section{According to John Stott}

" Exposition refers to the content of the sermon (biblical truth) rather than its style (a running commentary). To expound, the script is to bring out the text and expose it to view. The expositor opens what appears to be closed, makes plain what is obscure, unravels what is knotted, and unfolds what is tightly packed. " [43]

John Stott emphasizes that expository sermons are actually based more on biblical data and information than on those based on expert comments. He laments the actions of many preachers today. Yet the willful manipulation of Scripture by those who are determined to make it mean what they want it to mean has been a constant disgrace to the Church. [44] As Professor A. Vinet of Lausanne put it in the middle of the last century, "a passage of Scripture has a thousand times served for a passport to ideas which were not scriptural."[45] Sometimes, it has been the comparatively harmless hunt for an appropriate text ... Sometimes, however, a preacher misuses Scripture because he is riding a pet theological hobby-horse. An educational expert named Haddon Robinson said that preaching is,

"The communication of a biblical concept derived from a context of grammatical and literary study of its context, which the Holy Spirit first applies to the personality and experience of the preacher then through him to hearers."'[46]

Haddon Robinson put more emphasis on the transmission process through hirtoricalgramatical analysis and literature studies. In the meantime the Holy Spirit works and makes the preaching experience a part of the application of the biblical concept that is being investigated.

With the exposition and correct understanding of expository sermons, Word of God will show its strength in changing one's life. 
Solid expository preaching brings scripture to life. It connects the meaning of the passage to the life of the hearer, helping them to apply what they've heard to their specific life situations.

\section{WHY EXPOSITORY PREACHING}

\section{It lets God speak for Himself in the way $\mathrm{He}$ has spoken.}

God has communicated Himself in Scripture in a distinct way. Sticking to the Scriptures also helps us focus on what God says is most important. This is why expository preaching sets the table for God to speak for Himself-it seeks to communicate God's message the way $\mathrm{He}$ has already communicated, using main points and subpoints to communicate the original author's intent and aim of a passage.[47]

\section{It teaches people how to read their Bibles.}

Reading the Bible can be confusing. When a preacher faithfully preaches the Scripture and explains how he draws conclusions from the Scripture, the congregation sees faithful Bible reading modeled and are more equipped to do it themselves. This is the benefit of expository preaching: congregants will not depend on preaching as their only source of nourishment, but will over time grow in their ability to feed on Scripture themselves, and thus further their own Christian maturity. [48]

\section{HERMENUTICS GUARDS AGAINST FALSE TEACHING.}

False teachers are promised in Scripture. One of the purposes of teaching and preaching the Word is to lead to Christian maturity. Peter Mead ,[49] contributes to suggest two moves that need to take place in our understanding of preaching. Move 1. A shift from preaching well-crafted lists of tips for life, to genuinely understanding and then applying the Bible to our lives (or even applying our lives to the Bible). This is fundamentally a hermeneutics issue. After all, preaching involves the fruit of the preacher's hermeneutics communicated to the community... True exposition should not be disconnected from real life, for in the incarnation we see God giving of Himself, His ultimate self-revelation, in the most relevant manner imaginable."
Move 2 - From Well-Informed Biblical Exposition to Heart-Level Biblical Exposition... I affirm the importance of good learning in the areas of hermeneutics and biblical studies. I believe our skill in Bible study and sermon preparation should be informed by the best that the academy has to offer. The field of homiletics can, and must, teach methodology and 'how to.' Yet, this must be integrated with genuine spirituality, for the central calling of preachers is to be listeners to God's Word, prayerfully attentive to God's self-revelation in His Word and communicators of that divine devotion to the community of God's people.

\section{Expository Preaching Helps People Understand Their Bible.}

Expository preaching aids in the understanding of Scripture.Robert L Thomas said," The unique contribution of Bible Exposition is its substantial enhancement of the listeners' comprehension of Scripture's intent. Such a service is the ideal way to cooperate with the Holy Spirit who inspired Scripture as He takes an improved grasp of the text's meaning and shows its applicational significance to individual listeners. That is the best avenue for building up the saints.[50] Hughes mentions ,"[51] Hermeneutics is also an art because the interpreter needs to decide what principles of interpretation to use on a given biblical text, the order they should be used, and the weight they should give to each principle. The application of hermeneutical principles to a text is called exegesis." Kerry Mc Gonigal, "Here we have hermeneutics (faithfully) and homiletics (taught) brought together to accomplish something beautiful and powerful (the voice of God . . . authentically heard)." [52]

While there are other helpful ways to preach the Scriptures, there is one method of preaching that should never be abandoned or ignored: the expository method. Preachers should make this method a high priority in their ministry. The expository method of preparing content is demanded by Scripture and should not be abandoned. [53]

\section{CONCLUSION}

Secularization can not be blammed as the the cause of people leaving the church or their faith. We need to find what exactly the root cause of that problem. When religious matters are shifted progressively from the supernatural realm to the mundane one, some christian have failed to pass on our faith in 
Christ to the next generation. Secularism is a derivative of secularization. It is a kind of idiology that absolutizing of the value of this world which is againts the Christian theology. In this advanced age, secularism greatly overshadows the lives of believers. It confuses our minds from a supernatural God who is not easily accepted by human thought. So that believers need true spiritual food that is able to face thoughts that weaken their belief in God.

The preacher's jobs is to deliver accurately and effectively to his listeners what the Holy Spirit meant when $\mathrm{He}$ inspired the writers to pen the Scriptures. Church should respond to maturing the people in faith and understanding of God, church and pastors must provide comprehensive education, through expository sermon.

That is hearing the othentic God's will, through the exposition of word of God in the scripture. Expository preching is the only model of sermon which requires interpreting God's Word accurately, expository preaching requires knowledge of how to study the Bible. Hermeneutics is the field of study that seeks to define principles for studying the Bible in the most objective way.The only way to save the future generation from secularism is to make them know more and deeper about God through the Bible (expository of scripture) with the help of Holy Spirit and experienced Him in daily life.

\section{REFERENCES}

[1].http://www.pewforum.org/2011/06/22/glob al-survey-of-evangelical-protestant-leaders/

[2]. Alfonso Pérez-Agote, 2010,

'Secularization: Drawing the boundaries of its validity',Sociopedia.isa,DOI:10.1177/2056846 01075, pp. 1

[3]. Fuad Hassan, Pengantar Filsafat Barat, (Jakarta: Dunia Pustaka, 1996), h. 69 - 71.

[4]. Dobbelaere, Karel (2011) The Meaning and Scope of Secularization. This is chapter 33 (pages p600) of "The Oxford Handbook of The Sociology of Religion"

[5]. Tschannen, O. (1992) Les Théories de la sécularisation. Librairie Droz, Geneva.

[6]. Peter L. Berger, The Sacred Canopy: Elements of a Sociological Theory of Religion (New York: Doubleday \& Company, 1969), h. 109-125.
[7]. Ibid, h. 109-125.

[8]. Peter L. Berger, The Sacred Canopy: Elements of a Sociological Theory of Religion (New York: Doubleday \& Company, 1969), p. 109-125

[9]. Ibid.

[10]. Ibid.p. 20

[11]. Pardoyo, Sekularisasi Dalam Polemik, (Jakarta: Pustaka Utama, 1993), p. 82

[12]. Ibid. pp 12

[13]. Charles Taylor, 2007, “The Secular Age", The Belknap Press of Harvard University Press, p.15

[14]. Cox. Harvey; The Secular City: Secularization and Urbanization in Theological Perspective, Penguin Books, Victoria, Australia, 1965, pp.31

[15]. Bloesch. Donald G,1968, 'The Christian Witness in secular Age" an evaluation of nine contemporary theologians. Augsburg Publishing House, Minneapolis, Minesota, USA,pp. 104

[16]. Ibid, pp 107

[17].https://www.merriamwebster.com/diction ary/secularism

[18]. https://www.ldoceonline.com/Sociologytopic/secularism.

[19]. Iversen H.R. (2013) Secularization, Secularity, Secularism. In: Runehov A.L.C., Oviedo L. (eds) Encyclopedia of Sciences and Religions. Springer, Dordrecht.

[20]. Holyoake, GJ (1896). English Secularism: A Confession of Belief. University of California Libraries, $\mathrm{p} 1$.

[21]. Holyoake, GJ (1872). The Reasoner. Vol 30th.Turner and Co. London. p. 100.

[22].Holyoake, GJ (1896). English Secularism , p. 35 .

[23]. Holyoake, GJ (1872). The Reasoner, p. 100.

[24]. Cox. Harvey; The Secular City: Secularization and Urbanization in 
Theological Perspective, Penguin Books, Victoria, Australia, 1965, pp.34

[25]. Ibid, pp.73

[26]. Ibid.

[27]. Pratt, Vernon. (1970) Religion and Secularization. St. Martin's Press. Glasgow, pp 2

[28]. Ibid,pp 3

[29]. Karl Barth, Dogmatics in Outline, trans, GT Thomson (NY., Philosophical Library,nd), p.26 yang dikutip oleh Bloesch. Donald G,1968, 'The Christian Witness in secular Age" an evaluation of nine contemporary theologians. Augsburg Publishing House, Minneapolis, Minesota, USA,pp. 39

[30]. Ibid.

[31]. Emil Brunner, "Toward a Missionary Theology" in the Chistian Century. 1949, p. 817.Bloesch. Donald G,1968, 'The Christian Witness in secular Age" an evaluation of nine contemporary theologians. Augsburg Publishing House, Minneapolis, Minesota, USA,pp. 45

[32]. ibid. pp 48.

[33]. Rudolf Bultman,"A Reply to the theses of J. Schniewind," in Kerygma and Myth, I, ed. Hans W. Bartsch, trans. Reginald Fuller (London, SPCK,1960), p. 123. Cited by Bloesch. Donald G,1968, 'The Christian Witness in secular Age" an evaluation of nine contemporary theologians. Augsburg Publishing House, Minneapolis, Minesota, USA,pp. 54

[34]. Ibid,pp. 55

[35]. Ibid

[36]. Ibid. pp 56

[37]. Dietrich Boenhoeffer, The Cast of Discipleship, trans, RH Fuller (London, SCM Press, Ltd., 1959),pp 166. Cited by Bloesch. Donald G,1968, 'The Christian Witness in secular Age" an evaluation of nine contemporary theologians. Augsburg Publishing House, Minneapolis, Minesota, USA,pp. 85 [38].https://www.gospelherald.com/articles/71 104/20170711/billy-graham-rise-secularismsign-living-last-days.htm di akses 19/10/2018: 10.57

[39].https://www.gospelherald.com/articles/71 104/20170711/billy-graham-rise-secularismsign-living-last-days.htm di akses 19/10/2018: 10.57

[40]. Church Leaders and Declining Religious Service Attendance, By Frank Newport, https://news.gallup.com/opinion/pollingmatters/242015/church-leaders-decliningreligious-service-attendance.aspx

[41]. James Smetanin May 26, 2017, https://reformedalliance.com/2017/05/26/theimportance-of-expository-preaching

[42]. Preaching: How to Preach Biblically. John MacArthur Pastor's Library. 2005

[43]. Between Two Worlds: The Challenge of Preaching Today. (Grand Rapids: William B. Eerdmans Publishing Company, 1982), pp 198.

[44]. Between Two Worlds: The Challenge of Preaching Today (Grand Rapids: William B. Eerdmans Publishing Company, 1982) 130131. 